\title{
Editorial
}

International archives of
Allergy
Immunology

\section{In the Summertime When the Weather Is Fine}

\author{
Enrique Fernández-Caldas
}

Inmunotek S.L., Madrid, Spain; University of South Florida College of Medicine, Tampa, Fla., USA

The production of specific IgE antibodies is a result of sensitization to a specific allergen, or allergens. Specific IgE measurement to Dermatophagoides pteronyssinus is a major diagnostic test for the detection of sensitization against $D$. pteronyssinus, but its role in predicting the clinical relevance of the allergen is unclear. In general, low IgE antibody levels indicate less probability of clinical disease, while high antibody titers show good correlation with clinical symptoms. The determination of circulating specific IgE antibodies provides a precise evaluation of sensitization to indoor and outdoor allergens.

The paper by Hervás et al. [1], published in a recent issue of International Archives of Allergy and Immunology, shows an interesting relationship between specific IgE levels to D. pteronyssinus and climate parameters. The study was conducted in Mallorca, Spain, from January 1 , 2001, to December 31, 2010. The population studied consisted of 24,463 individuals, and $67.2 \%$ were positive to $D$. pteronyssinus. The results showed a marked seasonal pattern of specific IgE levels to D. pteronyssinus which could be significantly correlated with changes in relative humidity and solar radiation [1]. Peak levels occurred from mid-autumn to winter, decreasing to minimum levels in early summer. This correlated with the highest radiation index and the lowest ambient humidity. A previous study in France also addressed the same issue in a large number of patients, obtaining similar results [2]. Benitah et al. [2] analyzed 8,435 measurements spread over 4 years. Significant seasonal and monthly variations were seen every year, with a maximum level in autumn or the beginning of winter. The domestic relative humidity had a signifi-

\section{KARGER}

Fax +4161306 1234

E-Mail karger@karger.com

www.karger.com (c) 2013 S. Karger AG, Basel

$1018-2438 / 13 / 1612-0097 \$ 38.00 / 0$

Accessible online at:

www.karger.com/iaa cant effect on the seasonal variation, with a mean shift of 2 months that could be explained by the length of the biological cycle of the mites.

The existence of a seasonal pattern for $D$. pteronyssinus-specific IgE is consistent with previous reports that show seasonal fluctuations in mite counts, or mite allergen concentrations. Mites are very sensitive to fluctuations in humidity and need more than $50 \%$ humidity for survival. In the case of Mallorca, the summers are dry and hot. However, in some areas of the world, mite counts increase in the more humid summer months and decrease when the heating season begins in the fall/winter [3]. In tropical regions, mite allergens do not exhibit strong seasonal fluctuations [4]. Therefore, in order to establish, or predict, a cause relationship between specific IgE levels and mite allergen exposure, seasonal patterns of mite allergens should be established.

An important question remains unanswered: how large should the reduction in mite allergen levels be to produce a significant decrease in specific IgE levels? Was this level of reduction achieved in this study? This question is difficult to answer based on the present data, since mite allergen levels were not evaluated, and seasonal patterns of mite allergen levels have not been published. Future prospective studies should address this issue.

Piacentini et al. [5] analyzed serum IgE and IgG4 in a group of asthmatic children, aged between 7 and 17 years admitted to a residential house located $1,756 \mathrm{~m}$ above sea level. This area is known for a very low exposure to mite allergens. All patients were skin prick test positive to at least two of the following allergens: D. pteronyssinus, D. farinae, 
cat epithelium, timothy grass pollen, and Parietaria pollen. During the 180 days of hospitalization, serum-specific IgE were measured 6 times. A significant decrease in serumspecific IgE to house dust mite and pollen allergens was observed [5]. This observation is in agreement with a reduction in specific IgE levels due to a reduction in allergen exposure at home, along with a decrease in the time the children spend indoors due to better weather conditions outdoors, which in turn conditions mite allergen exposure.

However, the study has some limitations such as its ecological nature, which precludes applying its results from a population level to an individual level, the absence of information on the patients' clinical situation, or the ongoing therapy, and the lack of follow-up of individual patients. It is possible that some of the patients included were sensitized to mites, but mites were not the main cause of their allergic problem. Fewer mite-allergic patients may have consulted for allergies due to other allergens during the summer months. However, as stated in the paper, the large sample size and the quite local population exposed to very similar environmental factors, including climate, reduces biases derived from its design. Much clearer information could have been gathered if individual patients had been followed throughout the year on a monthly basis and dust samples had been collected and analyzed prospectively. However, these studies are very difficult to control and to perform.

Other factors which could have influenced the results are missing from the analysis. Adjuvants such as endotoxins or viral particles which could be present in the en- vironment and induce an increase in specific IgE levels to mite allergens in mite-allergic individuals were not contemplated. Seasonal variation studies of endotoxin levels have shown a marked increase in endotoxin concentrations at the end of the summertime and a significant correlation with deterioration of symptoms in mite-allergic children [6]. Other factors influencing specific IgE levels include parasitic infestations. However, it is not likely that parasites may have played a role in the results obtained in this study, although this possibility could also have been explored by following specific IgE levels to Ascaris spp.

Another plausible explanation for the results is vitamin D levels [7]. Sunlight is responsible for the synthesis of vitamin $\mathrm{D}$, and a growing number of reports have suggested that vitamin D plays an important role in regulation of the immune system and allergic diseases [8]. Vitamin D influences B lymphocyte functions and modulates the humoral immune response including secretion of IgE [9]. Mast cells and eosinophils are further vitamin $\mathrm{D}$ targets and increased cutaneous vitamin $\mathrm{D}$ synthesis increases IL-10 production in mast cells, which leads to suppression of skin inflammation [10].

The results presented in this study are in agreement with other related findings, such as a reduction in the number of visits to the emergency rooms for asthma [11] and in the number the viral infections during the summer time [12]. Although no data is available about the clinical status of the subjects enrolled into the study, the summertime seems to be the best time of the year for asthma sufferers, especially if they are mite allergic and live in Mallorca.

\section{References}

$>1$ Hervás D, Pons J, Milá J, Matamoros N, Hervás JA, García-Marcos L: Specific IgE levels to Dermatophagoides pteronyssinus are associated with meteorological factors. Int Arch Allergy Immunol 2013;160:383386.

$>2$ Benitah E, Guinnepain MT, David B, Terrenoir L, Herman D, de Felice P: Seasonal changes in specific IgE: the acarid Dermatophagoides pteronyssinus. Allerg Immunol (Paris) 1987;19:388-389, 391-392.

$>3$ Arlian LG, Bernstein IL, Gallagher JS: The prevalence of house dust mites, Dermatophagoides spp, and associated environmental conditions in homes in Ohio. J Allergy Clin Immunol 1982;69:527-532.

4 Fernández-Caldas E, Puerta L, Caraballo L, Mercado D, Lockey RF: Sequential determinations of Dermatophagoides spp. allergens in a tropical city. J Investig Allergol Clin Immunol 1996;6:98-102.
Piacentini GL, Guerresi S, Kantar A, Lubrano L, Olivieri F, Boner AL, Peroni DG: A comparison between IgE and IgG4 as markers of allergy in children: an experimental trial in a model of natural antigen avoidance. Int J Immunopathol Pharmacol 2011;24: 1049-1056.

6 Rizzo MC, Naspitz CK, Fernández-Caldas E, Lockey RF, Mimiça I, Solé D: Endotoxin exposure and symptoms in asthmatic children. Pediatr Allergy Immunol 1997;8:121-126.

7 Arnedo-Pena A, García-Marcos L, Fernández-Espinar JF, Bercedo-Sanz A, AguinagaOntoso I, González-Díaz C, et al: Sunny hours and variations in the prevalence of asthma in schoolchildren according to the International Study of Asthma and Allergies (ISAAC) Phase III in Spain. Int J Biometeorol 2011;55:423-434.

$>8$ Reinholz M, Ruzicka T, Schauber J: Vitamin $\mathrm{D}$ and its role in allergic disease. Clin Exp Allergy 2012;42:817-826.
Hartmann B, Heine G, Babina M, Steinmeyer A, Zugel U, Radbruch A, et al: Targeting the vitamin $\mathrm{D}$ receptor inhibits the $\mathrm{B}$ celldependent allergic immune response. Allergy 2010;66:540-548.

10 Biggs L, Yu C, Fedoric B, López AF, Galli SJ, Grimbaldeston MA: Evidence that vitamin $\mathrm{D}(3)$ promotes mast cell dependent reduction of chronic UVB induced skin pathology in mice. J Exp Med 2010;207:455-463.

-11 Gergen PJ, Mitchell H, Lynn H: Understanding the seasonal pattern of childhood asthma: results from the National Cooperative Inner-City Asthma Study (NCICAS). J Pediatr 2002;141:631-636.

12 Lee WM, Lemanske RF Jr, Evans MD, Vang F, Pappas T, Gangnon R, Jackson DJ, Gern JE: Human rhinovirus species and season of infection determine illness severity. Am J Respir Crit Care Med 2012;186:886-891. 